\title{
ANALISIS OPTIMASI TARGET 235U PENGKAYAAN RENDAH (LEU) UNTUK MENDUKUNG PRODUKSI 99MO DAN TARGET BATU TOPAZ DI REAKTOR RSG-GAS
}

\section{OPTIMIZATION ANALYSIS OF THE LEU (235U) TARGET FOR 99MO PRODUCTION SUPPORT WITH THE TOPAZ STONE TARGETS IN RSG-GAS REACTOR}

\author{
Sutrisno, Elisabeth Ratnawati, Fitri Susanti \\ Pusat Reaktor Serba Guna - BATAN \\ Kawasan Puspiptek Gd. No.31 Serpong Tangerang Selatan 15310 \\ soe-tris@batan.go.id
}

Diterima 5 Desember 2017, diterima dalam bentuk perbaikan 12 Januari 2018, disetujui 1 Maret 2018

\begin{abstract}
ABSTRAK
ANALISIS OPTIMASI TARGET 235U PENGKAYAAN RENDAH (LEU) UNTUK MENDUKUNG PRODUKSI 99Mo DAN TARGET BATU TOPAZ DI REAKTOR RSG-GAS. Peningkatan utilitas produksi radioisotop di reaktor RSG-GAS, seperti produksi ${ }^{99}$ Mo dan target batu topaz perlu upaya optimasi iradiasi target ${ }^{235} \mathrm{U}$ pengkayaan rendah (LEU) di dalam teras reaktor RSGF-GAS. Terdapat 4 posisi IP (Irradiation Position) yang saat ini digunakan untuk iradiasi batu topaz secara rutin dari 8 posisi iradiasi yang tersedia di dalam teras reaktor. Oleh karena itu, iradiasi target yang lain hanya dapat dilakukan di posisi CIP (Central Irradiation Position). Penelitian ini bertujuan untuk menganalisis jumlah target LEU yang optimum di posisi CIP dan iradiasi batu topaz di IP RSG-GAS. Ruang lingkup penelitian ini meliputi pemantauan batasan keselamatan operasi faktor puncak daya radial maksimum, margin reaktivitas padam saat stuck rod dan perubahan fluks neutron di detektor un-balanced load. Pendekatan perhitungan menggunakan metode difusi neutron 2dimensi, Batan-2DIFF dengan asumsi target LEU menggunakan proses electroplating. Hasil perhitungan menunjukkan jika seluruh posisi CIP diisi penuh target LEU dengan massa optimal 14,4 g (1,2 g per kapsul) dan $36 \mathrm{~g}$ (3 g per kapsul) diperoleh 0,72\% $\Delta \mathrm{k} / \mathrm{k}$ dan 1,12 \% $\Delta \mathrm{k} / \mathrm{k}$ jika dibandingkan dengan safety margin sebesar $2 \% \Delta \mathrm{k} / \mathrm{k}$ maka seluruh parameter teras masih memenuhi syarat batas keselamatan operasi.
\end{abstract}

Kata kunci: ${ }^{99} \mathrm{Mo}$, batu topaz, radioisotop, electroplating, reaktor RSG-GAS.

\section{ABSTRACT}

OPTIMIZATION ANALYSIS OF THE LEU (235U)TARGET FOR ${ }^{99}$ MO PRODUCTION SUPPORT WITH THE TOPAZ STONE TARGETS IN RSG-GAS REACTOR. The RSG-GAS reactor is suitable utilized for radioisotope production, such as ${ }^{99} \mathrm{Mo}$, because it has high neutron flux and some in-core irradiation positions. There are 8 in-core irradiation positions in the reactor and 4 IP (Irradiation Position) have been used for the routine irradiation of topaz stone targets. Therefore, the irradiation of other targets should be carried out in the CIP (Central Irradiation Position) position. The objective of these researchs to analyze the optimum number and mass of the irradiated low enrichment fuel targets (LEU) in the CIP with the topaz stone targets. The LEU target is electroplated in the inner capsule for the radioisotope production of $99 \mathrm{Mo}$. The safety limit value, such as maximum radial power peaking factor, one stuck rod shutdown margin and neutron flux changes at the un-balanced load detectors, are used as the optimization of the targets. The core calculation has been carried out by using the 2-dimensional multi group neutron diffusion method code, Batan-2DIFF. The calculation results showed that if all CIP positions were fully fulfilled with the LEU targets with the total mass of $14.4 \mathrm{~g}$ (1.2 g per capsule) and $36 \mathrm{~g}$ (3 g per capsule was obtained $0.72 \% \Delta \mathrm{k} / \mathrm{k}$ and $1.12 \% \Delta \mathrm{k} / \mathrm{k}$ when it was compared to the safety margin of $2 \% \Delta \mathrm{k} / \mathrm{k}$ all core parameters still fulfilled to the safety limit value.

Keywords: ${ }^{99} \mathrm{Mo}$, topaz stone, radioisotope, electroplating, RSG-GAS reactor. 


\section{PENDAHULUAN}

P encitraan pemanfaatan radioisotop hampir $80 \%$ untuk diagnosa kedokteran nuklir menggunakan teknisium$99 \mathrm{~m}\left({ }^{99} \mathrm{mTc}\right)$ yang merupakan anak luruh dari radionuklida molybdenum-99 $\left({ }^{99} \mathrm{Mo}\right)$ [1]. Sejak terjadinya pemadaman 2 reaktor penghasil ${ }^{9}$ Mo pada tahun 2008, NRU (National Research Universal, Kanada) dan HFR (High Flux Reactor, Belanda), maka kepastian produk ${ }^{99} \mathrm{Mo}$ berkelanjutan menjadi isu global yang sangat penting $[2,3]$. Banyak metode produksi yang digunakan, yaitu dengan cara mengiradiasi target di teras reaktor dan pemercepat partikel $[4,9]$. User reaktor RSG-GAS (Reaktor Serba Guna G.A. Siwabessy) menggunakan iradiasi target U-235 pengkayaan rendah (low enrichment uranium), yaitu dalam bentuk electroplating dan foil, sertamolibdenum alam $\left(\mathrm{MoO}_{3}\right)$ untuk menghasilkan ${ }^{99} \mathrm{Mo}[4,5,7,10]$. Metode target electroplating digunakan secara rutin di reaktor RSG-GAS untuk produksi ${ }^{99}$ Mo di pasar domestik maupun ekspor.

Diprediksi permintaan pasar lokal untuk ${ }^{99} \mathrm{Mo}$ akan meningkat, sehingga penentuan kapasitas maksimum reaktor RSG-GAS mengiradiasi target LEU dalam bentuk electroplating perlu dilakukan. Kajian tentang target electroplating LEU yang optimum di reaktor RSG-GAS telah dilakukan oleh Pinem et al.[10]. Penelitian dilakukan dengan optimasi untuk target tunggal ataupun campuran dengan target radioisotop (RI) lainya, seperti $\mathrm{TeO}_{2}$ (menghasilkan ${ }^{131}$ ) [11,12], $\mathrm{Gd}_{2} \mathrm{O}_{3}$ (menghasilkan ${ }^{161} \mathrm{~Tb}$ ) [13], $\mathrm{MoO}_{3}$ dan $\mathrm{Sm}_{2} \mathrm{O}_{3}$ (menghasilkan ${ }^{153} \mathrm{Sm}$ ). Posisi iradiasi divariasi jumlahnya untuk IP (Irradiation Position, 4 posisi kisi teras) dan CIP (Central Irradiation Position, 4 posisi kisi teras). Akan tetapi untuk saat ini dan seterusnya, posisi IP tidak mungkin lagi diisi target elctroplating LEU, karena telah diisi target batu topaz [14]. Penelitian sebelumnya menunjukkan bahwa iradiasi batu topaz di posisi IP reaktor RSG-GAS memberikan perubahan reaktivitas yang positif [15]. Optimasi iradiasi target electroplating LEU bersama dengan target yang memberi reaktivitas positif, seperti topaz, belum pernah dilakukan. Oleh karena itu optimasi iradiasi target electroplating LEU di CIP yang dilakukan bersama dengan target topaz yang maksimum perlu dilakukan. Tujuan penelitian ini adalah untuk menentukan jumlah target electroplating LEU yang optimum di posisi CIP reaktor RSG-GAS saat diiradiasi bersama target batu topaz.

Optimasi dilakukan dengan paket progran Batan-2DIFF dan WIMSD5 yang telah tervalidasi dan digunakan dalam penelitian sebelumnya [7,16]. Perhitungan sel target batu topaz dan LEU dilakukan dengan paket program WIMSD5B dengan data nuklir ENDF/B-VII.1[17] dalam 4 kelompok tenaga neutron. Perhitungan teras dilakukan dengan paket program metode difusi neutron 2-dimensi (2-D), Batan-2DIFF, dalam model geometri $X-Y$. Penentuan target radiasi yang optimum dengan metode difusi neutron telah dilakukan dalam beberapa penelitian sebelumnya [7,10].

Batasan yang digunakan dalam optimasi target LEU adalah sebesar $2 \% \Delta \mathrm{k} / \mathrm{k}$ margin pada saat kondisi stuck rod, perubahan reaktivitas, perubahan faktor puncak daya dan perubahan fluks neutron di detektor unbalanced. Batasan ini dipilih untuk menjamin reaktor dalam keadaan aman dan dapat dioperasikan dengan normal. Massa target LEU per kapsul akan disesuaikan dengan massa target yang diizinkan regulator dan massa maksimum yang digunakan dalam penelitian sebelumnya [7].

Makalah ini menyajikan deskripsi reaktor dan target LEU sebelum penyajian metodologi. Dalam bagian ini akan dijelaskan juga tentang posisi dan konfigurasi target di teras selain model sel target. Hasil dan pembahasan disajikan dan ditutup dalam kesimpulan dan saran.

\section{DESKRIPSI TERAS RSG-GAS DAN TARGET BAHAN BAKAR LEU}

Reaktor RSG-GAS adalah reaktor riset jenis MTR (Material Testing Reactor) dengan daya nominal 30 MW (termal) [7]. Teras reaktor RSG-GAS disusun oleh 48 elemen bakar standar (EB) dan 8 elemen bakar kendali (EK) dan beberapa elemen refelektor berilium $(\mathrm{Be})$ dalam $10 \times 10$ posisi kisi teras seperti ditunjukkan dalam Gambar 1.Teras menyediakan beberapa posisi untuk iradiasi target yaitu CIP (central irradiation posistion), IP (irradiation position), PNRS (pneumatic rabbit system) dan HYRA (hydraulic rabbit system) yang masing-masing terdiri dari 4, 4, 1 dan 3 posisi kisi teras. Target yang membutuhkan waktu iradiasi yang lama menggunakan posisi CIP atau IP. Blok reflektor berilium berbentuk "L" diletakkan di dua sisi teras untuk meningkatkan fluks neutron yang akan dipakai di tabung berkas neutron yang diletakkan di blok reflektor 
tersebut. Bahan bakar menggunakan uranium silisida $\left(\mathrm{U}_{3} \mathrm{Si}_{2}-\mathrm{Al}\right)$ pengkayaan rendah $(\leq 19,75 \%)$ dengan tinggi aktif teras adalah $60 \mathrm{~cm}$.

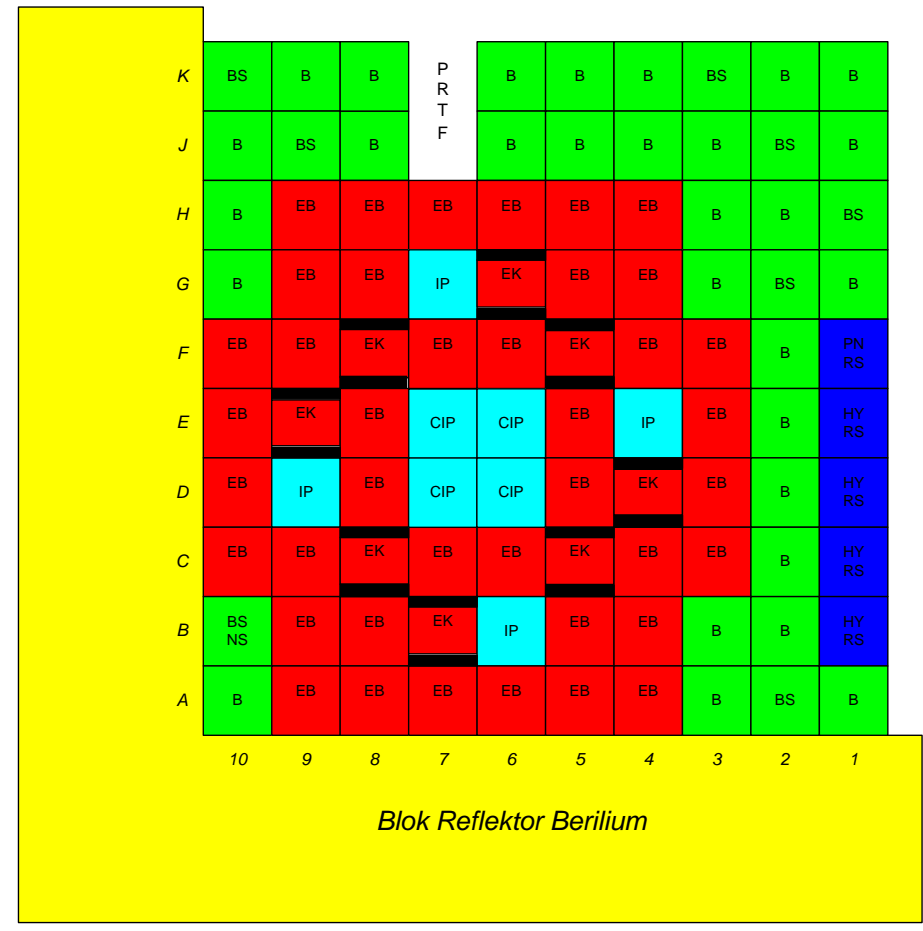

Keterangan $:$ EB = Elemen bakar standar; $\mathrm{EK}=$ Elemen bakar kendali; $\mathrm{B}=$ Elemen refelektor $\mathrm{Be}$; $\mathrm{BS}=$ Elemen refelektor Be dengan plug; IP = Irradiation Position; CIP = Central Irradiation Position; PNRS = Pneumatic Rabbit System; HYRS = Hydraulic Rabbit System; NS = sumber neutron

\section{Gambar 1. Konfigurasi teras reaktor RSG-GAS [7].}

Posisi CIP dan IP dipakai untuk mengiradiasi target yang membutuhkan fluks neutron termal rerata yang tinggi, seperti target untuk produksi isotop. Pada daya nominal, fluks neutron termal rerata di CIP dan IP sebesar $2 \times 10^{14}$ neutron $\mathrm{cm}^{-2} \mathrm{~s}^{-1}$. Oleh karena itu CIP dan IP cocok digunakan untuk iradiasi bahan bakar LEU dalam produksi radioisotop ${ }^{99} \mathrm{Mo}$. Saat ini seluruh posisi IP (B-6, D-9, E-4 dan G-7) dipakai untuk iradiasi batu topaz [14], sehingga iradiasi target lainnya dalam teras hanya diperbolehkan di CIP (D-6, D-7, E-6 dan E-7).

Target batu topaz diletakkan dalam satu wadah alumunium yang berdiameter luar dan dalam masingmasing sebesar $5,08 \mathrm{~cm}$ dan 4,68 cm, seperti ditunjukkan dalam Gambar 2. Wadah ini diberi nama keranjang (basket). Tinggi maksimum target batu topaz yang diperbolehkan diiradiasi perkeranjang adalah $45 \mathrm{~cm}$ atau setara dengan berat maksimum sebesar 2,7 kg. Dengan demikian massa 1 batch iradiasi (4 posisi IP) adalah sebesar 10,8 kg.

Target bahan bakar LEU untuk produksi radioisotop ${ }^{99}$ Mo diletakkan di posisi CIP. Radioisotop ${ }^{99} \mathrm{Mo}$ yang terbentuk diperoleh sebagai hasil pembelahan neutron dengan uranium yang ada di dalam tabung stainless steel (SS304L) [18]. Target LEU berupa uranium logam dengan pengkayaan $\leq 19,75 \%$ ditempelkan di permukaan dalam SS-304L dengan cara electroplating. Diameter luar dan dalam kapsul SS-304L masingmasing adalah $3 \mathrm{~cm}$ dan 2,8 cm dengan tinggi tabung $45,49 \mathrm{~cm}$ (tidak termasuk tutup kapsul). Tinggi daerah target bahan bakar yang ditempelkan ke kapsul adalah $40 \mathrm{~cm}$. Gambar 3 menunjukkan kapsul yang digunakan untuk target LEU. Laporan Analisis target LEU menyatakan bahwa massa maksimum uranium dalam target adalah $3 \mathrm{~g}$ akan tetapi izin dari regulasi adalah $1,2 \mathrm{~g}$ [18]. 


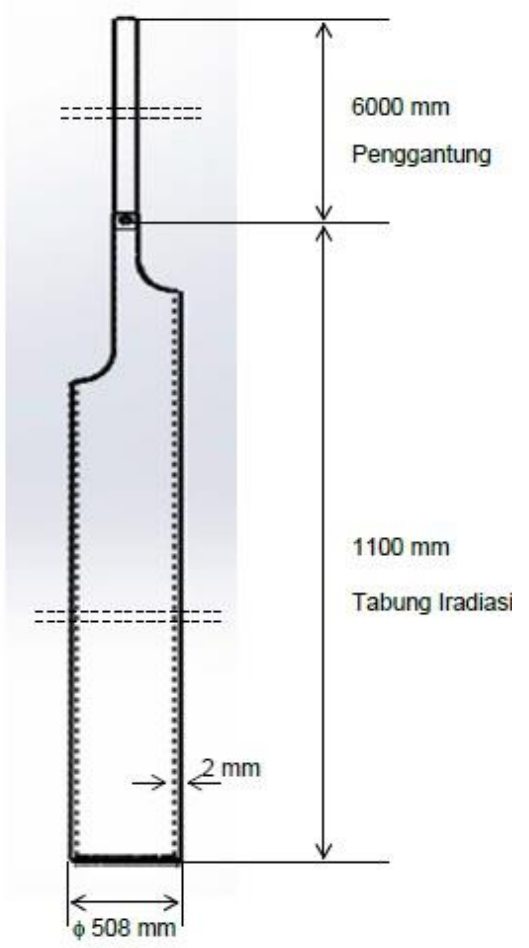

Gambar 2. Keranjang alumunium target batu topaz.
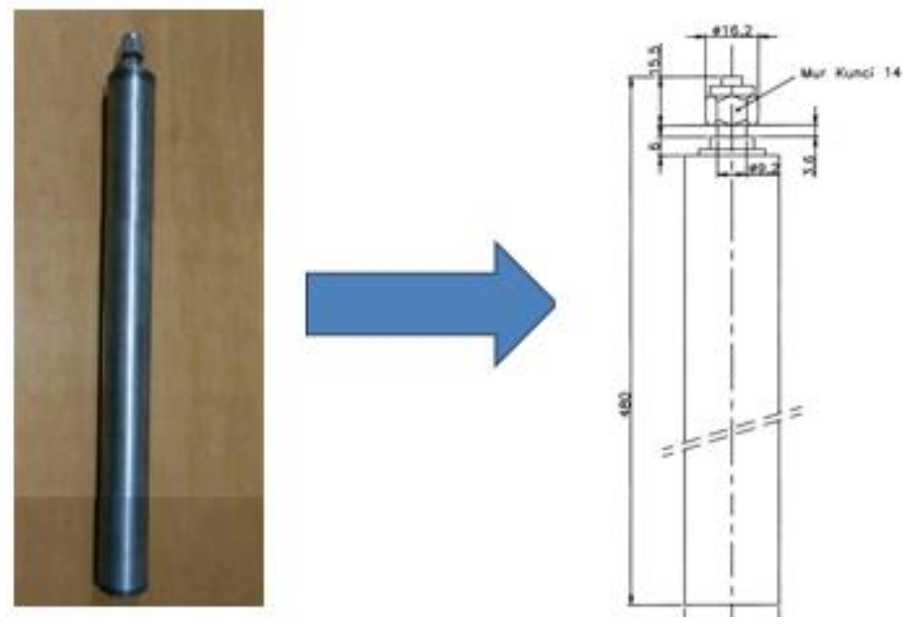

Gambar 3. Tabung kapsul target LEU.

Iradiasi target dalam kapsul memerlukan stringer yang berfungsi sebagai pengarah agar target berada pada posisi yang ditentukan. Stringer yang digunakan di reaktor RSG-GAS tersaji dalam Gambar 4, yang diletakkan dalam satu posisi kisi teras, dengan demikian satu posisi kisi CIP dapat mengiradiasi 3 kapsul. Seluruh target dalam kapsul yang diiradiasi dalam teras reaktor RSG-GAS diletakkan di stringer. Penetapan orientasi stringer di CIP dengan adanya target LEU dan target batu topaz di CIP ditunjukkan di Gambar 5, dan Gambar 5 tersebut akan menjadi acuan untuk optimasi dalam penelitian ini. 


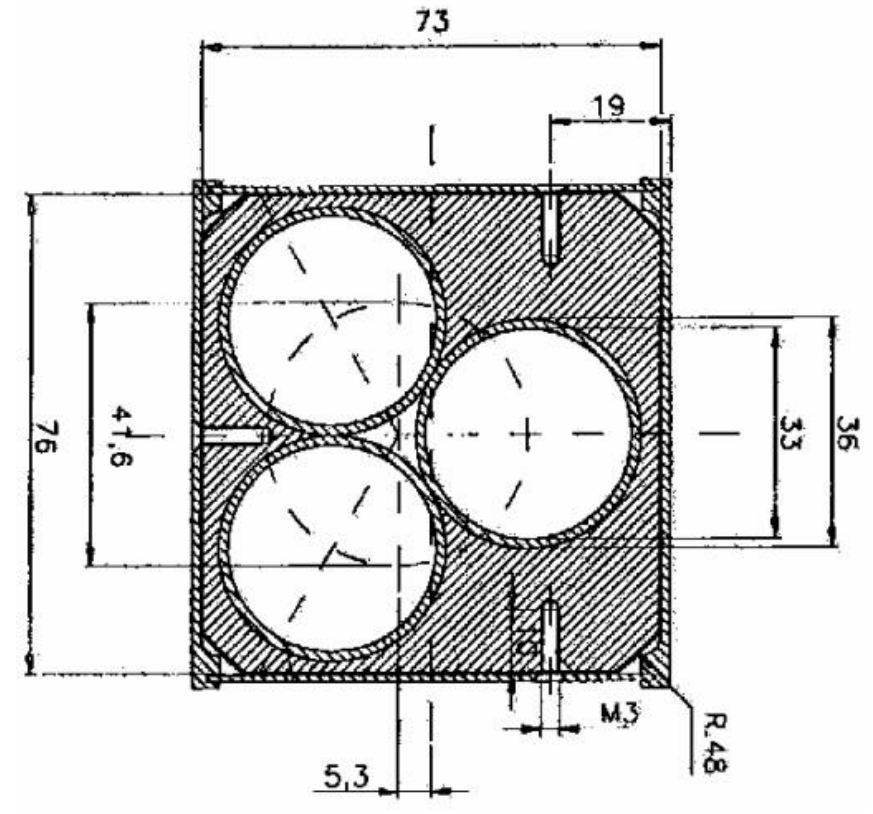

Gambar 4. Stringer kapsul target [7].
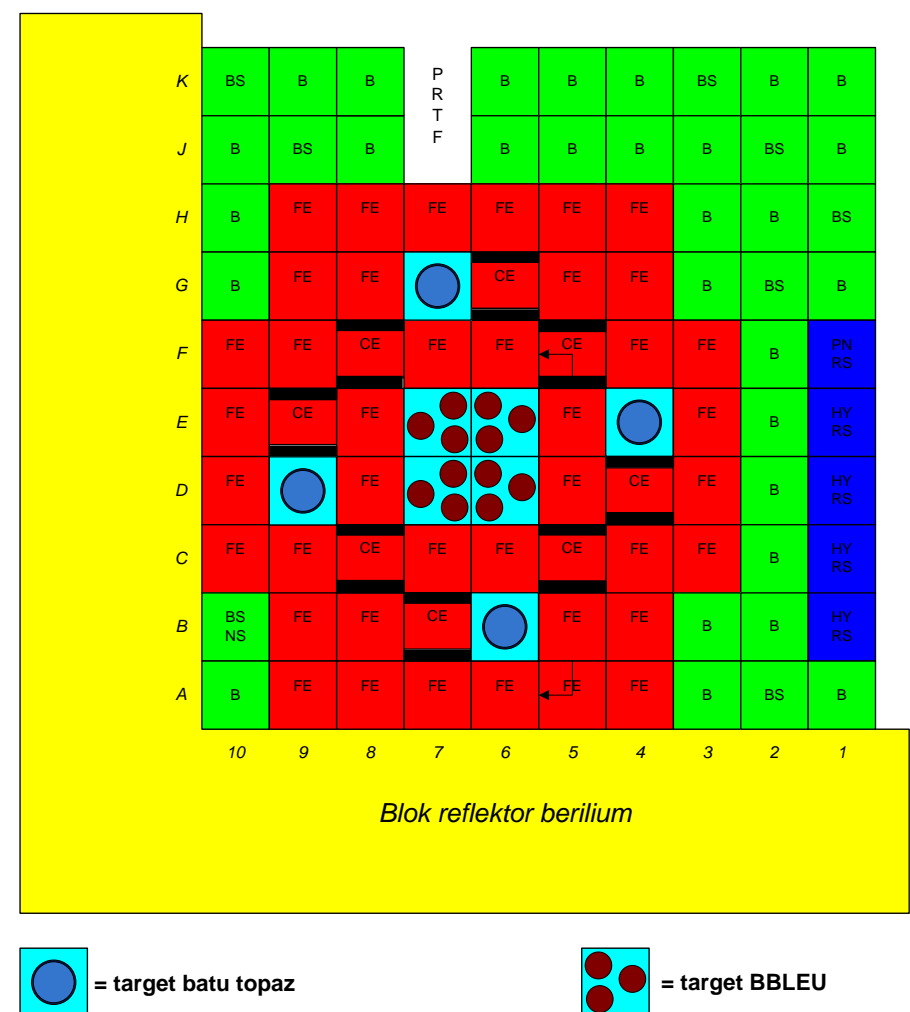

= target BBLEU

Gambar 5. Penetapan konfigurasi target topaz dan LEU di reaktor RSG-GAS. 


\section{METODOLOGI}

Perhitungan sel target batu topaz dan LEU dilakukan dengan paket program WIMSD5B untuk menggenerasi konstanta kelompok dalam 4 kelompok tenaga neutron dengan data nuklir ENDF/B-VII.1 [7,17]. Batas atas (upper boundary) kelompok tenaga neutron adalah $10 \mathrm{MeV}, 0.821 \mathrm{MeV}, 5,530 \mathrm{keV}$ dan $0,625 \mathrm{eV}$. Dalam perhitungan sel ditetapkan bahwa tinggi target batu topaz di keranjang dan LEU di kapsul masing-masing adalah $45 \mathrm{~cm}$ dan $40 \mathrm{~cm}$. Susunan target batu topaz dan LEU dari bagian bawah teras disajikan di Tabel 1 .

Tabel 1. Data ketinggian dan penyusun tiap zona target batu topaz dan LEU.

\begin{tabular}{lllll}
\hline \multirow{2}{*}{ Zona } & \multicolumn{2}{c}{ Target Batu Topaz } & \multicolumn{1}{c}{ Target LEU } \\
\cline { 2 - 5 } & $\begin{array}{l}\text { Ketinggian, } \\
\mathrm{cm}\end{array}$ & $\begin{array}{l}\text { Penyusun } \\
\text { (dari luar ke dalam) }\end{array}$ & $\begin{array}{l}\text { Ketinggian, } \\
\mathrm{cm}\end{array}$ & $\begin{array}{l}\text { Penyusun } \\
\text { (dari luar ke dalam) }\end{array}$ \\
\hline I & 45 & $\mathrm{H}_{2} \mathrm{O}, \mathrm{Al}$ dan batu topaz & 2,745 & $\mathrm{H}_{2} \mathrm{O}, \mathrm{Al}, \mathrm{H} 2 \mathrm{O}, \mathrm{SS}-304 \mathrm{~L}$ dan void \\
II & 15 & $\mathrm{H}_{2} \mathrm{O}$ dan Al & 40 & $\mathrm{H}_{2} \mathrm{O}, \mathrm{Al}, \mathrm{H}_{2} \mathrm{O}, \mathrm{SS}-304 \mathrm{~L}, \mathrm{LEU}$ dan void \\
III & & & 2,745 & $\mathrm{H}_{2} \mathrm{O}, \mathrm{Al}, \mathrm{H}_{2} \mathrm{O}, \mathrm{SS}-304 \mathrm{~L}$ dan void \\
IV & & & 14,51 & $\mathrm{H}_{2} \mathrm{O}, \mathrm{Al}$ dan SS-304L (tutup atas) \\
\hline
\end{tabular}

Sel target LEU dapat dimodelkan dalam 2 bagian, yaitu $1 / 2$ kisi dan $1 / 4$ kisi untuk setiap posisi di CIP sesuai dengan konfigurasi stringer yang digunakan. Model sel ini, seperti ditunjukkan dalam Gambar 6 , telah digunakan dalam penelitian sebelumnya yang menggunakan stringer yang sama [7]. Karena perhitungan teras dilakukan untuk 2-dimensi (2-D), maka seluruh bagian target dihogenisasi dalam 1 sel sesuai dengan fraksi volume dari masing-masing material penyusun sel seperti ditunjukkan dalan Tabel 2. Perhitungan sel dilakukan untuk:

1. Generasi konstanta kelompok difusi untuk target batu topaz ketinggian $45 \mathrm{~cm}$.

2. Generasi konstanta kelompok difusi untuk target LEU dengan model $1 / 4$ kisi posisi CIP (1,2 gU dan 3 $\mathrm{gU})$

3. Generasi konstanta kelompok difusi untuk target LEU dengan model $1 \frac{1}{2}$ kisi posisi CIP (1,2 gU dan $\left.3 \mathrm{gU}\right)$

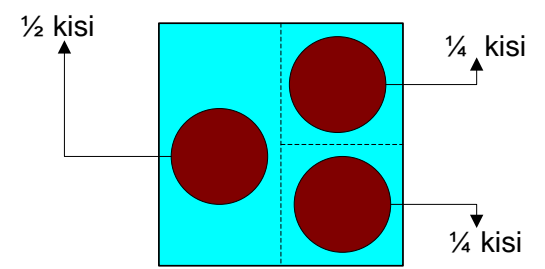

Gambar 6. Model $1 / 2$ dan $1 / 4$ kisi posisi CIP untuk target LEU[7].

Tabel 2. Fraksi volume material target LEU untuk tiap massa dan model.

\begin{tabular}{lllll}
\hline \multirow{2}{*}{ Material } & \multicolumn{2}{l}{ Fraksi volume $1,2 \mathrm{~g}$} & \multicolumn{2}{l}{ Fraksi volume $3 \mathrm{~g} \mathrm{U}$} \\
\cline { 2 - 5 } & $1 / 4 \mathrm{kisi}$ & $1 / 2 \mathrm{kisi}$ & $1 / 4 \mathrm{kisi}$ & $1 / 2 \mathrm{kisi}$ \\
\hline Al-stringer & 0,1041 & 0,0521 & 0,1041 & 0,0521 \\
$\mathrm{SS}-304$ & 0,0439 & 0,0220 & 0,0434 & 0,0217 \\
Uranium -LEU & 0,0003 & 0,0002 & 0,0009 & 0,0004 \\
$\mathrm{H}_{2} \mathrm{O}$ & 0,8516 & 0,9258 & 0,8516 & 0,9258 \\
\hline
\end{tabular}

Perhitungan teras menggunakan paket program BATAN-2DIFF sehingga teras penuh reaktor RSG-GAS, termasuk target, dimodelkan dalam model geometri X-Y (2-D) dengan syarat batas vacuum di tiap sisi teras [7]. Parameter teras yang dihitung adalah perubahan reaktivitas lebih teras $(\Delta \rho)$, perubahan faktor puncak daya radial maksimum ( $\Delta$ FPDRmax), perubahan fluks neutron di detektor unbalance load $(\Delta \phi)$, margin padam pada 
saat stuck rod ( $\rho S T)$ dan distribusi $\triangle$ FPDR di teras. Parameter teras ini berkaitan dengan parameter keselamatan yang memiliki nilai batas masing-masing FPDr maksimum, $\Delta \phi$ dan $\rho S T$ adalah $\leq 1,4, \leq 16 \%$ dan $\geq 0,5$. Nilai batas ini yang akan dipakai dalam menentukan massa target LEU yang optimum. Jika salah satu nilai batas terlampaui, maka kondisi target harus ditolak dalam optimasi. Tabel 3 menunjukkan kondisi teras yang dihitung dalam peneltian ini untuk variasi jumlah dan massa target LEU (1,2 g dan $3 \mathrm{~g}$ per kapsul). Parameter teras di Kasus-1 dipakai sebagai acuan untuk menentukan perubahan parameter teras akibat kasus pemasukan target topaz dan LEU (Kasus-2 - Kasus-25).

Tabel 3. Jumlah target FPM untuk tiap kasus.

\begin{tabular}{|c|c|c|c|c|c|c|}
\hline \multirow{2}{*}{$\begin{array}{l}\text { Nama } \\
\text { Kasus }\end{array}$} & \multirow{2}{*}{$\begin{array}{l}\text { Target Topaz } \\
\text { (basket) }\end{array}$} & \multicolumn{4}{|c|}{ Target LEU (jumlah kapsul) } & \multirow{2}{*}{$\begin{array}{l}\text { Massa Target } \\
\text { LEU* }, g^{-}\end{array}$} \\
\hline & & Kisi D-6 & Kisi D-7 & Kisi E-6 & Kisi E-7 & \\
\hline Kasus-1 & 0 & \multicolumn{4}{|c|}{ diisi stringer di masing-masing posisi } & 0 \\
\hline Kasus-2 & 4 & 0 & 0 & 0 & 0 & \\
\hline Kasus-3 & 4 & 0 & 0 & 0 & 1 & $1,2 / 3$ \\
\hline Kasus-4 & 4 & 0 & 0 & 0 & 2 & $2,4 / 6$ \\
\hline Kasus-5 & 4 & 0 & 0 & 0 & 3 & $3,6 / 9$ \\
\hline Kasus-6 & 4 & 0 & 0 & 1 & 0 & $1,2 / 3$ \\
\hline Kasus-7 & 4 & 0 & 0 & 2 & 0 & $2,4 / 6$ \\
\hline Kasus-8 & 4 & 0 & 0 & 3 & 0 & $3,6 / 9$ \\
\hline Kasus-9 & 4 & 0 & 1 & 0 & 0 & $1,2 / 3$ \\
\hline Kasus-10 & 4 & 0 & 2 & 0 & 0 & $2,4 / 6$ \\
\hline Kasus-11 & 4 & 0 & 3 & 0 & 0 & $3,6 / 9$ \\
\hline Kasus-12 & 4 & 1 & 0 & 0 & 0 & $1,2 / 3$ \\
\hline Kasus-13 & 4 & 2 & 0 & 0 & 0 & $2,4 / 6$ \\
\hline Kasus-14 & 4 & 3 & 0 & 0 & 0 & $3,6 / 9$ \\
\hline Kasus-15 & 4 & 3 & 0 & 0 & 3 & $7,2 / 18$ \\
\hline Kasus-16 & 4 & 0 & 3 & 3 & 0 & $7,2 / 18$ \\
\hline Kasus-17 & 4 & 0 & 0 & 3 & 3 & $7,2 / 18$ \\
\hline Kasus-18 & 4 & 3 & 3 & 0 & 0 & $7,2 / 18$ \\
\hline Kasus-19 & 4 & 0 & 3 & 0 & 3 & $7,2 / 18$ \\
\hline Kasus-20 & 4 & 3 & 0 & 3 & 0 & $7,2 / 18$ \\
\hline Kasus-21 & 4 & 3 & 3 & 3 & 0 & $10,8 / 27$ \\
\hline Kasus-22 & 4 & 3 & 3 & 0 & 3 & $10,8 / 27$ \\
\hline Kasus-23 & 4 & 0 & 3 & 3 & 3 & $10,8 / 27$ \\
\hline Kasus-24 & 4 & 3 & 0 & 3 & 3 & $10,8 / 27$ \\
\hline Kasus-25 & 4 & 3 & 3 & 3 & 3 & $14,4 / 36$ \\
\hline
\end{tabular}

Cataran $^{*}=$ massa LEU per kapsul untuk 2 jenis target $1,2 \mathrm{~g}$ dan $3 \mathrm{~g}$

\section{HASIL DAN PEMBAHASAN}

Tabel 4 menyajikan perubahan reaktivitas $(\Delta \rho)$, perubahan faktor puncak daya radial maksimum $(\Delta$ FPDRmax), perubahan fluks neutron di detektor unbalance load $(\Delta \phi)$ dan margin padam pada saat stuck rod ( $\rho S T)$. untuk seluruh kasus pemasukan target. Hasil perhtungan menunjukkan bahwa nilai $\Delta \rho$ naikdengan penambahan massa LEU per kapsul, dari $1,2 \mathrm{~g}$ menjadi $3 \mathrm{~g}$, untuk setiap kasus. Hal yang sama terjadi, nilai $\Delta \rho$ akan naik dengan penambahan kapsul di satu posisi teras (Kasus-3 - Kasus-14) demikian juga nilai $\Delta \rho$ akan naik dengan bertambahnya jumlah posisi kisi teras yang digunakan (Kasus-15 - Kasus-25). Hal ini diakibatkan dengan naiknya massa LEU per kapsul atau posisi target LEU di CIP maka jumlah reaksi pembelahan akan meningkat dengan demikian menaikkan nilai reaktivitas lebih teras. Nilai maksimum $\Delta \rho$ pada saat seluruh posisi 
CIP penuh target LEU untuk 14,4 $\mathrm{g}$ dan $36 \mathrm{~g}$ masing-masing adalah $0,72 \% \Delta \mathrm{k} / \mathrm{k}$ dan $1,12 \% \Delta \mathrm{k} / \mathrm{k}$. Nilai ini masih kurang dari nilai batas $2 \% \Delta \mathrm{k} / \mathrm{k}$.

Hasil perhitungan menunjukkan dengan jelas bahwa dengan naiknya nilai $\Delta \rho$ akan menurunkan margin padam saat stuckrod, $\rho S T$. Penurunan nilai $\rho S T$ untuk kasus pemuatan CIP penuh (Kasus-25) sebesar 43,6\% dan 56,8\% untuk masing-masing target $1,2 \mathrm{~g}$ dan $3 \mathrm{~g}$ LEU per kapsul atau total massa target sebesar $14,4 \mathrm{~g}$ dan $36 \mathrm{~g}$. Semakin besar massa target dimasukkan maka meningkatkan nilai $\Delta \rho$ dan menurunkan nilai $\rho S T$. Meskipun demikian, nilai $\rho S T$ untuk Kasus-25 tidak melenihi batas sebesar $-0,5 \% \Delta k / k$.

Efek setiap pemasukan target LEU terhadap perubahan nilai $\Delta \phi$ ternyata tidak menunjukkan sesuatu yang sistematis. Tidak ada korelasi yang dapat dibuat antara jumlah target atauposisi pemasukan target dengan $\Delta \phi$. Tabel 4 menunjukkan bahwa nilai $\Delta \phi$ maksimum terjadi pada Kasus-25 dan Kasus-17 masing-masing untuk target 1,2 g per kapsul dan $3 \mathrm{~g}$ per kapsul. Meskipun tidak maksimum Kasus-17 untuk target 1,2 g perkapsul membuat nilai $\Delta \phi>3 \%$, yaitu 3,09\%. Hal ini dapat dimengerti karena pada Kasus-17 posisi pemasukan dilakukan di posisi kisi teras E-6 dan E-7 (Tabel 3), sehingga gangguan fluks neutron lokal terjadi disekitar posisi tersebut sehingga kesetimbangan distribusi fluks neutron berubah sekitar $3 \%$. Meskipun demikian, nilai $\Delta \phi$ ini jauh lebih kecil dibanding nilai batas $16 \%$.

Tabel 4. Hasil perhitungan perubahan parameter teras untuk seluruh kasus.

\begin{tabular}{|c|c|c|c|c|c|c|c|c|}
\hline \multirow[b]{2}{*}{ Kasus } & \multicolumn{4}{|c|}{ 1,2 g LEU per kapsul } & \multicolumn{4}{|c|}{$3 \mathrm{~g}$ LEU per kapsul } \\
\hline & $\begin{array}{l}\Delta \rho, \% \\
\Delta \mathrm{k} / \mathrm{k}\end{array}$ & $\begin{array}{l}\Delta \text { FPDma } \\
\mathrm{x}\end{array}$ & $\Delta \phi, \%$ & $\begin{array}{l}\rho S T, \% \\
\Delta k / k\end{array}$ & $\begin{array}{l}\Delta \rho, \% \\
\Delta \mathrm{k} / \mathrm{k}\end{array}$ & $\begin{array}{l}\Delta \text { FPDma } \\
\mathrm{x}\end{array}$ & $\Delta \phi, \%$ & $\begin{array}{l}\rho S T, \% \\
\Delta k / k\end{array}$ \\
\hline Kasus-1 & - & - & - & $-2,50$ & - & - & - & $-2,50$ \\
\hline Kasus-2 & 0,21 & $-0,04$ & $-2,45$ & $-1,80$ & 0,21 & $-0,04$ & $-2,45$ & $-1,80$ \\
\hline Kasus-3 & 0,26 & $-0,03$ & $-2,41$ & $-1,74$ & 0,29 & $-0,03$ & $-2,37$ & $-1,71$ \\
\hline Kasus-4 & 0,30 & $-0,02$ & $-2,40$ & $-1,71$ & 0,36 & $-0,02$ & $-2,36$ & $-1,64$ \\
\hline Kasus-5 & 0,34 & $-0,01$ & $-2,49$ & $-1,67$ & 0,46 & $-0,02$ & $-2,53$ & $-1,56$ \\
\hline Kasus-6 & 0,26 & $-0,03$ & $-2,72$ & $-1,77$ & 0,29 & $-0,03$ & $-2,86$ & $-1,76$ \\
\hline Kasus-7 & 0,30 & $-0,03$ & $-2,70$ & $-1,75$ & 0,36 & $-0,03$ & $-3,03$ & $-1,70$ \\
\hline Kasus-8 & 0,33 & $-0,02$ & $-2,96$ & $-1,72$ & 0,42 & $-0,02$ & $-3,34$ & $-1,64$ \\
\hline Kasus-9 & 0,26 & $-0,02$ & $-2,09$ & $-1,77$ & 0,29 & $-0,02$ & $-1,88$ & $-1,75$ \\
\hline Kasus-10 & 0,30 & $-0,01$ & $-1,97$ & $-1,74$ & 0,36 & $-0,01$ & $-1,63$ & $-1,69$ \\
\hline Kasus-11 & 0,33 & 0,00 & $-1,76$ & $-1,72$ & 0,42 & 0,00 & $-1,23$ & $-1,65$ \\
\hline Kasus-12 & 0,26 & $-0,03$ & $-2,51$ & $-1,78$ & 0,29 & $-0,03$ & $-2,54$ & $-1,77$ \\
\hline Kasus-13 & 0,30 & $-0,02$ & $-2,49$ & $-1,76$ & 0,36 & $-0,02$ & $-2,52$ & $-1,72$ \\
\hline Kasus-14 & 0,33 & $-0,01$ & $-2,42$ & $-1,75$ & 0,42 & $-0,01$ & $-2,38$ & $-1,69$ \\
\hline Kasus-15 & 0,46 & 0,01 & $-2,45$ & $-1,60$ & 0,65 & 0,01 & $-2,43$ & $-1,44$ \\
\hline Kasus-16 & 0,46 & 0,02 & $-2,33$ & $-1,63$ & 0,64 & 0,02 & $-2,24$ & $-1,49$ \\
\hline Kasus-17 & 0,46 & 0,01 & $-3,09$ & $-1,58$ & 0,64 & 0,01 & $-3,64$ & $-1,39$ \\
\hline Kasus-18 & 0,46 & 0,02 & $-1,75$ & $-1,66$ & 0,64 & 0,03 & $-1,14$ & $-1,53$ \\
\hline Kasus-19 & 0,46 & 0,02 & $-1,73$ & $-1,58$ & 0,64 & 0,03 & $-1,17$ & $-1,40$ \\
\hline Kasus-20 & 0,46 & 0,01 & $-2,90$ & $-1,65$ & 0,64 & 0,00 & $-3,23$ & $-1,52$ \\
\hline Kasus-21 & 0,59 & 0,05 & $-2,29$ & $-1,56$ & 0,87 & 0,05 & $-2,16$ & $-1,35$ \\
\hline Kasus-22 & 0,59 & 0,05 & $-1,74$ & $-1,51$ & 0,88 & 0,06 & $-1,18$ & $-1,27$ \\
\hline Kasus-23 & 0,59 & 0,04 & $-2,36$ & $-1,49$ & 0,88 & 0,05 & $-2,30$ & $-1,22$ \\
\hline Kasus-24 & 0,59 & 0,03 & $-2,97$ & $-1,51$ & 0,88 & 0,03 & $-3,36$ & $-1,26$ \\
\hline Kasus-25 & 0,72 & 0,07 & $-3,31$ & $-1,41$ & 1,12 & 0,08 & $-2,10$ & $-1,08$ \\
\hline
\end{tabular}

Tabel 4 menunjukkan bahwa $\triangle$ FPDR maksimum terjadi pada Kasus-25 yaitu 0,07 dan 0,08 masingmasing untuk target $1,2 \mathrm{~g}$ per kapsul dan $3 \mathrm{~g}$ per kapsul. Hasil perhitungan teras untuk faktor puncak daya sebelum ada target LEU, Kasus-1, adalah 1,24. Terlihat jelas secara umum bahwa nilai $\triangle$ FPDr akan meningkat dengan bertambahnya jumlah target (bandingkan nilai Kasus-25 dengan Kasus-21 - Kasus-24). Nilai $\Delta$ FPDRmax 
lebih sensitif pada bertambahnya jumlah posisi dibanding dengan bertambahnya massa target. Hal ini diakibatkan dengan bertambahnya jumlah posisi, maka perubahan fluks neutron di sekitarnya juga akan bertambah. Penambahan target yang maksimum tidak melebihi nilai batas FPDR yaitu 1,4.

Nilai $\triangle$ FPDRmax di Tabel 4 tidak menunjukkan perubahan faktor puncak daya radial (FPDR) untuk setiap elemen bakar di teras akibat pemasukan target. Gambar 7 dan 8 menunjukkan perubahan FPDR ( $\triangle$ FPDR) untuk setiap elemen bakar reaktor RSG-GAS untuk Kasus-25. Distribusi nilai $\triangle$ FPDR di teras berkisar 0,01-0,22 dan -0,01-0,22 untuk Kasus-25 masing-masing dengan target 1,2 g dan $3 \mathrm{~g}$ per kapsul. Hal ini menunjukkan dengan posisi yang sama walaupun massa target per kapsul berbeda akan memberikan kisaran $\triangle F P D R$ yang relatif sama. Perubahan $\triangle$ FPDR yang realtif besar untuk Kasus- 25 terjadi pada elemen bakar di sekitar CIP, yaitu $0,07-0,22$. Nilai $\triangle$ FPDRmaksimum $(0,21-0,22)$ terjadi pada elemen bakar standar yang berbatasan langsung dengan CIP dan IP.

Nilai $\triangle$ FPDR sebesar 0,22 identik dengan 2,86 MWD jika teras seperti konfigurasi di Gambar 7 dan 8 dioperasikan dalam satu siklus. Sebagai catatan, satu siklus identik dengan 600 MWD. Mengingat hampir seluruh elemen bakar mengalami perubahan FPDR kecuali di posisi kisi teras A-4, A-8, A-9, H-4, H-5 dan H-9 (Gambar 8), maka efek perubahan fraksi bakar perlu dievaluasi terhadap parameter kritikalitas teras jika konfigurasi ini dioperasikan.

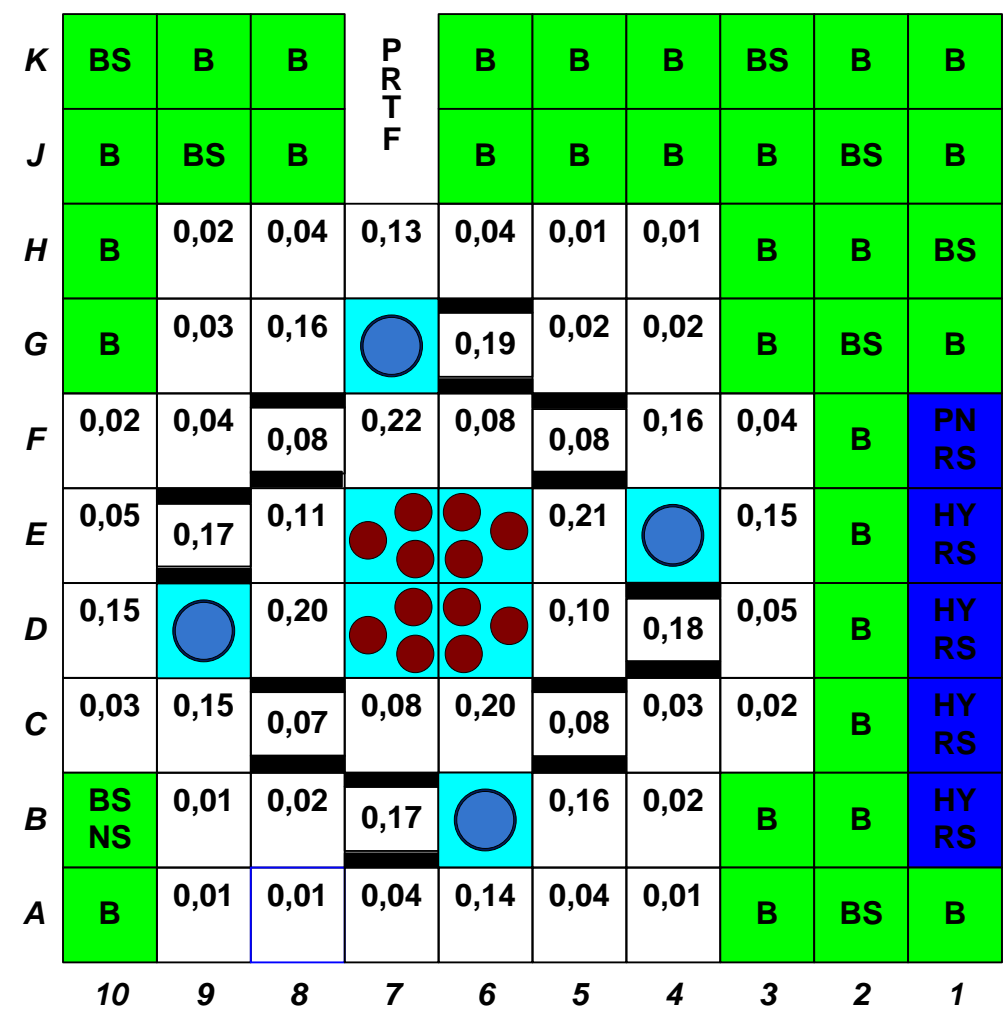

Gambar 7. Distribusi $\triangle$ FPDR di teras RSG-GAS untuk Kasus-25 dengan target $1,2 \mathrm{~g}$ per kapsul. 


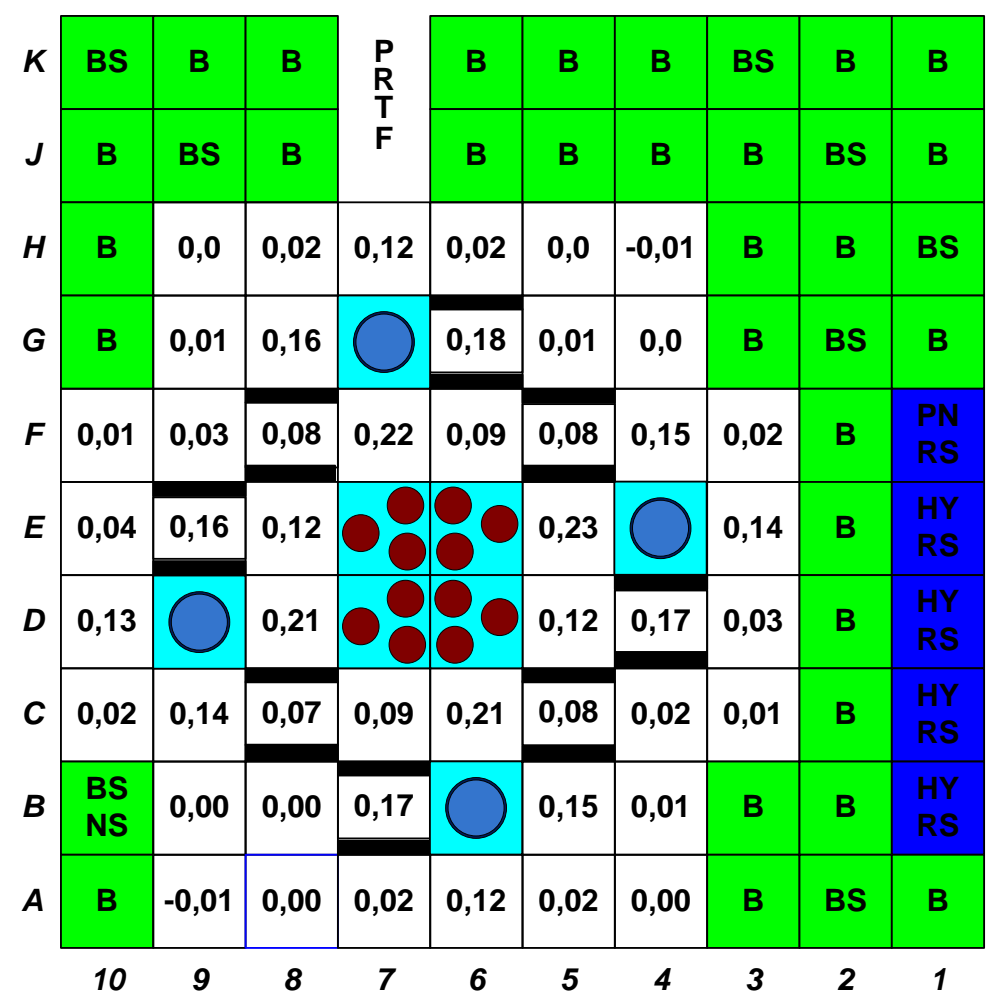

Gambar 8. Distribusi $\triangle F P D R$ di teras RSG-GAS untuk Kasus-25 dengan target $3 \mathrm{~g}$ per kapsul.

Hasil penelitian Kuncoro [19] menyatakan bahwa aktivitas sebesar $291 \mathrm{Ci} /$ minggu akan diperoleh dengan target $11,5 \mathrm{~g}$. Dengan demikian jika posisi CIP reaktor RSG-GAS diisi penuh dengan target LEU sebesar $1,2 \mathrm{~g}$ dan $3 \mathrm{~g}$ per kapsul masing-masing dapat menghasilkan ${ }^{99} \mathrm{Mo}$ dengan aktivitas sebesar $364 \mathrm{Ci} /$ minggu dan $911 \mathrm{Ci} /$ minggu.

\section{KESIMPULAN}

Hasil perhitungan menunjukkan jika seluruh posisi CIP teras reaktor RSG-GAS dipakai untuk iradiasi target 235 $\mathrm{U}$ pengkayaan rendah dengan massa $1,2 \mathrm{~g}$ dan $3 \mathrm{~g}$ per kapsul, maka diperoleh hasil $0,72 \% \Delta \mathrm{k} / \mathrm{k}$ dan $1,12 \% \Delta \mathrm{k} / \mathrm{k}$ dan bila dibandingkan batasan keselamatan sebesar $2 \% \Delta \mathrm{k} / \mathrm{k}$ tidak ada yang dilampaui.

\section{UCAPAN TERIMAKASIH}

Penelitian ini dilakukan dengan dana DIPA tahun 2017 Pusat Reaktor Serba Guna BATAN. Penulis mengucapkan terimakasih kepada Bapak Tagor Malem Sembiring yang telah membantu dan membimbing dalam mempersiapkan perhitungan sel dan teras.

\section{DAFTAR PUSTAKA}

[1] OECD-NEA, The Supply of Medical Radioisotopes. 2017 Medical Isotope Supply Review: ${ }^{99 M o} / 99 \mathrm{mTc}$ Market Demand and Production Capacity Projection, pp 2017-2022 , 2017.

[2] P. Gold, Nature, 460, pp 312-313, 2009.

[3] M. Ahmad, G. VandegrifTand P. Cristini, Sci. Technol. Nucl. Install., pp.2014, 2014. 
[4] NATIONAL RESEARCH COUNCIL OF THE NATIONAL ACADEMIES, Medical Isotope Production Without Highly Enriched Uranium (2009).

[5] I. Saptiama, Herlina, Sriyono, E. Sarmini, Abidin and Kadarisman, Urania, 99, pp.121-132, 21016.

[6] A. J. Hummel, Molybdenum-99 Production in the Oregon State TRIGA Reactor: Analysis of the Reactor Design using a new LEU Target as Fuel, Oregon State University , 2013.

[7] S. Pinem, T. M. Sembiring and P. H. Liem, Atom Indonesia,42, pp. 123-128, 2016.

[8] P. H. Liem, H. N. Tram, and T. M. Sembiring, Prog. Nucl. Energy, 82, pp. 191-196, 2015.

[9] A. Isnaeni, M. Aljohani, T. Aboalfaraj and S. Bhuiyan, Atom Indonesia, 40, pp. 40-43, 2014.

[10] S. Pinem, J. Susilo, Tukiran and T. Sembiring, Teknologi. Indonesia, 35, pp. 37-45, 2012.

[11] A. Fllaoui et al., Nucl. Eng. Technol., 48, pp. 1273-1279, 2016.

[12] B. El Bakkari, B. Nacir, T. El Bardouni, C. El Younoussi, Y. Boulaich and H. BoukhaL, Ann. Nucl. Energy, 78, pp. 140-145, 2015.

[13] A. Aziz and W. T. Artha, Indonesia J. Chem., 16, pp. 283-288, 2016

[14] E. Ratnawati, K. Mustofa dan A. Hidayat, "Pengaruh Irradiasi Batu Topaz Terhadap Kualitas Pendingin Reaktor G.A. Siwabessy," di ProsidingSeminar Nasional Teknologi dan Aplikasi Reaktor Nuklir, PRSGBATAN, pp. 34-39, 2012.

[15] Sutrisno, "Perhitungan reaktivitas batu topaz $1,5 \mathrm{~kg}$ posisi D-9 dengan program BATAN-2DIFF,"di Prosiding Seminar Nasional Teknologi dan Aplikasi Reaktor Nuklir, PRSG-BATAN, pp. 143-152, 2012.

[16] S. Pinem, P. H. Liem, T. M. Sembiring and T. Surbakti, Ann. Nucl. Energy, 98, pp. 211-217, 2016.

[17] A. C. Kahler et al., Nucl. Data Sheets, 112, pp. 2997-3036, 2011.

[18] PRSG BATAN, Laporan Analisis Keselamatan Iradiasi Target FPM-LEU Elektroplating.Addendum Ke-2 Terhadap : Analisis Keselamatan Iradiasi Target FPM di Teras RSG GAS, No . Ident . RSGOFI-FPM Revisi 1 Laporan Analisis Keselamatan Iradiasi Target FPM-LEU Elektroplating, PRSG BATAN, pp. 135, 1993.

[19] S. Kuntjoro, Sigma Epsilon, 20, pp. 13-20, 2016. 